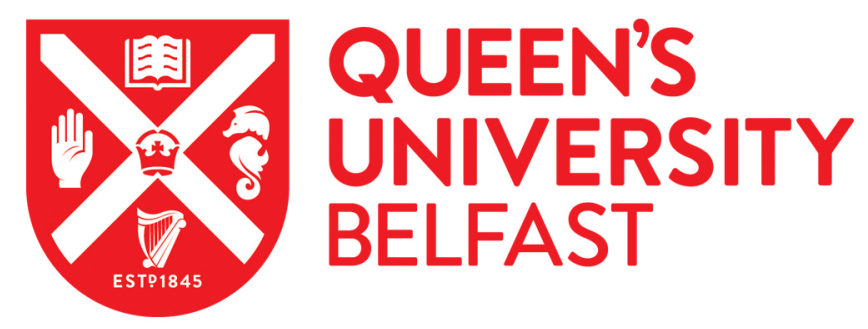

\title{
Through the lens of the hospital magazine - Downshire and Holywell psychiatric hospitals in the 1960s and 1970s
}

Prior, P. M., \& McClelland, G. (2013). Through the lens of the hospital magazine - Downshire and Holywell psychiatric hospitals in the 1960s and 1970s. History Of Psychiatry, 24(4), 399-414.

https://doi.org/10.1177/0957154X13500594

Published in:

History Of Psychiatry

Document Version:

Peer reviewed version

Queen's University Belfast - Research Portal:

Link to publication record in Queen's University Belfast Research Portal

\section{General rights}

Copyright for the publications made accessible via the Queen's University Belfast Research Portal is retained by the author(s) and / or other copyright owners and it is a condition of accessing these publications that users recognise and abide by the legal requirements associated with these rights.

Take down policy

The Research Portal is Queen's institutional repository that provides access to Queen's research output. Every effort has been made to ensure that content in the Research Portal does not infringe any person's rights, or applicable UK laws. If you discover content in the Research Portal that you believe breaches copyright or violates any law, please contact openaccess@qub.ac.uk. 


\title{
Through the lens of the hospital magazine: Downshire and Holywell psychiatric hospitals in the I960s and I970s
}

History of Psychiatry $0(0) 1-16$

(C) The Author(s) 2013 Reprints and permissions: sagepub.co.uk/journalsPermissions.nav DOI: 10.1 177/0957|54XI3500594 hpy.sagepub.com

(SAGE

\section{Pauline Prior}

Queen's University, Belfast

\section{Gillian McClelland}

Queen's University, Belfast

\begin{abstract}
An exploration of the pages of two psychiatric hospital magazines, Speedwell from Holywell Hospital, Antrim, and The Sketch from Downshire Hospital, Downpatrick, reveals the activity filled lives of patients and staff during the 1960s and 1970s. This was a time of great change in mental health care. It was also a time of political turbulence in Northern Ireland. With large in-patient populations, both hospitals had a range of occupational and sporting activities available to patients and staff. The magazines formed part of the effort to promote the ethos of a therapeutic community. While hospital magazines may be viewed as one aspect of an institutional system that allowed people to cut themselves from the wider society, they also provided opportunities for budding writers to express their views on life in a hospital from the service-user perspective. As such they offer some valuable insights into the lives of psychiatric patients.
\end{abstract}

\section{Keywords}

Hospital magazine, Northern Ireland, psychiatry, 1960s, 1970s

Most histories of mental health services are written with a 'top down' approach. This is understandable in the light of the fact that very few patients were given a chance to write about life in a psychiatric hospital. However, some did air their views in hospital magazines/newsletters, which flourished in the mid-twentieth century. Here, we look at two: Speedwell, the magazine of Holywell Hospital, Antrim, which was published quarterly from 1959 to 1973, and The Sketch, the magazine of Downshire Hospital, Downpatrick, published monthly from 1965 to 1987. This article is based on a complete run of Speedwell from the summer 1959 to December 1973 and a substantial run of The Sketch from August 1967 to December 1982.

\section{Corresponding author:}

Pauline Prior, Senior Lecturer Social Policy, School of Sociology, Social Policy and Social Work Queen's University, Belfast BT9 5GZ, UK.

Email: paulineprior@virginmedia.com 


\section{Hospital magazines}

Goffman's (1961) study of 'total institutions' in the USA in the 1950s suggested that among the practices that developed to bond staff and patients together in mutual support and understanding was the hospital magazine.

The printed content is such as to draw a circle around the institution and to give the accent of public reality to the world within ... The writing is done by inmates but expresses the official view of the functions of the institution, the staff's theory of human nature, an idealised version of inmate-staff relationships, and the stance an ideal convert ought to take - in short, it presents the institutional line. (Goffman, 1961: 96)

Hospital magazines developed in the early decades of the twentieth century in the UK, the US and Canada. However, until recently the genre has not attracted much academic interest, with the exception of Reznick's (2004) study of hospital magazines during World War I. These publications developed from Trench Journals: by 1915, nearly every military hospital produced a Trench Journal under the heading of 'literary projects'. The format included an editorial by the commanding officer or matron, pen and ink sketches of hospital life, institutional recreation news, concert announcements, 'censored humour about staff, patients and ward life', as well as advertisements by local businesses (Reznick, 2004: 68). Some of these early hospital magazines were used by architects to promote their designs and planning agenda among hospital staff, while others served 'as a professional version of popular home design magazines' (Adams, 2008: 96; Friedman, 2004: 76). For hospital managers, the magazine could also be viewed as a public relations exercise (Mills, 1965).

\section{Speedwell}

Speedwell magazine was first published in the summer of 1959 and continued on a quarterly basis until the end of 1973. The proclaimed purpose of the publication was to support the policy of the Resident Medical Superintendent (RMS), Dr G.M. Smith, to establish a 'therapeutic community' within the hospital. It aimed to appeal to 'patients, staff, their friends, and any other persons interested in the life of the Hospital'. Dr Smith wrote in the first issue: 'Here patients and staff work together; their work, recreation and social activities are all centred around the idea of treatment, this means the solving of personal problems, the easing of emotional distress, the arousing of new interests. (Speedwell, Summer 1959: 2)

Each issue of Speedwell included news about hospital events and personalities, a parson's page, notes on health and beauty, sport and various homilies and competitions. It also had articles on patient activities such as outings and holidays, as well as poems, letters and artwork. This was in keeping with the magazines of the time, as explored by Gavigan (1963: 244): 'Preference was shown for material dealing with the calendar of events and reports of activities and events occurring at the hospital, fiction, humour, editorials, sports, cartoons and articles dealing with mental hygiene.'

Speedwell differed from some of the more prestigious hospital magazines in that patients as well as staff could contribute. However, the editorial side was dominated by staff ( 23 staff members were on the editorial committee at one stage), and very few patients were involved in deciding what was included in each issue.

\section{The Sketch}

This newsletter at the Downshire Hospital was published monthly from late 1965 until 1987, and it was also seen as part of the therapeutic community approach to mental health care (Kelly, 2012). 
It was run from the occupational therapy department, overseen by Tom Page and Simon O'Reilly, but edited and printed by patients, two of whom were very proud to be associated with the magazine and with the hospital: Winifred Gray and Peter Lawson. Both patients and staff contributed to the contents, which included articles, letters and poems, with the artwork - depicting a sign of the zodiac on the cover of each issue - being completed by patients. Most contributions were signed, sometimes with an initial instead of a name, but always with a ward number also. Those who wrote in it were proud of their efforts. Most of the content is light-hearted and optimistic, with an air of movement and fluidity as staff and patients sent greetings as they changed jobs or were discharged to a new life outside the hospital.

The Sketch is interesting not only because of what it tells us about life in this large psychiatric hospital at a time of great change in approaches to mental health care, but also because it was published during two decades of extreme political violence in Northern Ireland. Staff and patients occupied a sheltered space within a society torn by sectarianism and political division. The "troubles' were reported rarely in The Sketch, when events or outings had to be cancelled due to bomb scares or riots, and sometimes featured in patient poetry.

\section{The hospitals}

Downshire Hospital opened as the Down Asylum in 1869 with 330 beds. Holywell Hospital opened in 1899 as Antrim Asylum with 400 beds. In 1921 when Ireland was divided politically, both hospitals became part of the Northern Ireland Health Service, at first managed by local councils (1921-48), then by the Northern Ireland Hospitals Authority (NIHA) (1948-73) and finally, from 1973 onwards, by integrated Health and Social Services Boards/Trusts (Prior, 1993a). Patient numbers increased continuously in both hospitals in the first half of the twentieth century, reaching a high point at the end of the 1950s. By then Holywell had 827 patients and Downshire over 1100 (Kelly, 2012: ch.6; Mulholland, 1999: 67). In line with trends elsewhere, patient numbers decreased in Holywell in the 1960s and, when the magazine ceased production in 1973, they had fallen to 611 (Mulholland, 1999: 67). At Downshire, patient numbers did not begin to decrease until the 1970s; by the time the magazine closed in 1987, the number of patients had reduced to around 500 (Kelly, 2012: ch.6).

According to historians of the two hospitals - Marc Mulholland (1999) for Holywell and Sean Kelly (2012) for Downshire - they were both integrated into the local communities. This was probably due to the fact that they were major sources of employment for both men and women. In addition, throughout the 1950s and 1960s, they were social venues, with dances, concerts and sporting events open to the public. At Holywell, the monthly dances often attracted crowds of over 500 people, and all the well-known 'show-bands' of the era played there. Dinner dances, though less frequent, were also attended by prominent local people (Mulholland, 1999: 25).

Psychiatric hospitals in Northern Ireland during the early decades of the twentieth century had been places of confinement rather than of treatment and care. Following the Mental Treatment Act (NI)1932, there were some changes, including allowing patients to wear their own clothes, a growing emphasis on regular patient entertainment and the introduction of occupational therapy based on a model developed in the Netherlands (Prior 1993a: 50). Insulin therapy and electroconvulsive therapy (ECT) were introduced to Northern Ireland in the mid 1940s, though Dr B.M. Lothian (RMS at the Downshire) was slightly sceptical about these therapies (Prior, 1993a: 51). Real change came in the post-war era of the 1950s, when the contribution of Northern Ireland to the British war effort was rewarded by a financial commitment from the UK governmentto the building of a comprehensive health service in Northern Ireland similar to that in other parts of the UK. 
This led to a massive expansion in mental health services which had been severely underfunded for decades (Prior, 1993b: 323).

At the same time, new ideas began to filter through from specialist centres such as the Tavistock Clinic, London, ideas which included that of a 'therapeutic community' as proposed by Dr Maxwell Jones in the mid-1940s (Manning, 1989). According to ideas at the time, some of which still prevail, the therapeutic community should be ideologically grounded. 'Based on ideas of collective responsibility, citizenship and empowerment, therapeutic communities are deliberately structured in a way that encourages personal responsibility and avoids unhelpful dependency on professionals' (Campling, 2001: 365). Some of these ideas had already influenced psychiatry in Northern Ireland, as evidenced in the discussions that led to the passing the Mental Health Act (NI)1948, which had no counterpart in other parts of the UK, but paralleled similar legislation in the Republic of Ireland: Mental Health Act 1945 (Prior, 1993a: 56-72).

During the 1960s and 1970s the patient experience began to change, due not only to the influence of radical ideas such as those of Dr Maxwell Jones and of the anti-psychiatry movement (Barton, 1959; Goffman, 1961), but also to the impact of medical developments and of economic pressures on the public purse. Following what Jones (1993: 179) terms the 'pharmacological revolution' of the 1950s, the role of the mental hospital as a place of confinement for untreatable conditions was subjected to scrutiny. Enoch Powell, the UK Minister of Health 1960-63, seized the opportunity to suggest a radical reform of the mental hospital system, arguing in 1961 for a reduction in mental health beds by more than 50 per cent over the next 15 years (Beckett, 2006; Powell, 1961). The principles underpinning this policy had been outlined in the recommendations of the Royal Commission on the Law relating to Mental Illness and Mental Deficiency 1954-1957: 'There should be a general re-orientation away from institutional care in its present form and towards community care' (GB Royal Commission, 1957). This principle was enshrined in the Mental Health Acts 1959 (England and Wales) and 1961 (Northern Ireland) and had a profound impact on hospital life in the decades that followed.

From the 1970s onwards, the general policy thrust was to integrate mental health services more fully into the general health and social care structure and to focus on community rather than on in-patient care. In October 1973, both Holywell and Downshire Hospitals came under the management of the newly integrated health and social services structures, with Holywell directly managed from the Northern Health and Social Services Board and Downshire from the Eastern Health and Social Services Board. From the 1980s, patient numbers in both hospitals declined, and in 2012 Downshire closed as a psychiatric hospital, while Holywell continued to provide a range of specialist mental health services.

\section{The therapeutic community}

Downshire (previously known as Down Hospital) had prided itself on promoting the idea of a therapeutic community since the 1930s. In the Annual Report for 1930 we read: "Medical advances would include equipment for "electro-medical and hydro-therapeutic treatments" and "moral" treatment would include an occupational therapy room - a room set aside for "non-essential work" (Down Hospital, 1930: xvi, cited in Prior, 1993a: 50).

All non-medical activities with a therapeutic value were organized from the occupational therapy department which had seven members of staff by 1960 (Kelly, 2012: ch.7). The idea of a therapeutic community was based on assumptions of genuine communication and respect between patients and staff, a flattening of power differentials, and a movement away from the hierarchical structures of a hospital. How this was possible is difficult to visualize as this was a time when the 
patient population was at its highest, with over 1100 patients in Downshire throughout the 1960s. However, there is no doubt that large numbers of patients took part in a range of activities that gave meaning and power to their lives.

Underpinning all the activities, there seemed to be a genuine attempt to facilitate communication between staff and patients. In 1967 in The Sketch we read about the monthly meeting of patients and staff, which included representatives from every ward and the five senior members of hospital staff: Dr Dougal (the RMS), Mr Flynn (Secretary), Miss O' Hare (Matron), Mr Lees (Chief Male Nurse), and Mr Dunbar (Catering officer) (Sketch, Oct. 1967: 4). A meeting between patients and a group of senior staff such as this is unthinkable today, but this kind of meeting was held in the board-room of Downshire at 9.00 p.m. on the first Monday of every month throughout the 1960s. According to the report in this issue of The Sketch, the topics discussed included: where to hold the regular dance, whether or not tea could be supplied at the dance, the possibility of having a fry and porridge on Sunday mornings, and where to go on the next coach outing. Other more serious concerns were also discussed at these meetings, and ward representatives were free to voice complaints from patients on any aspect of hospital life.

At Holywell, the idea of a therapeutic community had been taken further in the newly established Day Hospital, where a decision was made not to employ an occupational therapist, but rather to allow patients to organize their own activities. According to the consultant, Dr Roger Whiteley:

For a trial period of one year (1962) the Day Hospital has not asked for an occupational therapist and instead has dealt with occupational, recreational and social activities on a therapeutic-community basis, that is to say the patients themselves have been responsible for programming their own activities, usually through a committee. This venture has been highly successful and I feel that, in general, the patients have been happier and more responsible individuals. A fully qualified occupational therapist, or even an assistant with long experience, would not easily fit into our present therapeutic community atmosphere (Mulholland, 1999: 66).

We do not know how long this experiment lasted, but it is likely that even if tolerated under the management of the NIHA prior to 1973, it would not have been allowed to continue under the Eastern Health and Social Services Board management as efforts were made to standardize services throughout Northern Ireland.

At Downshire the initiatives were mostly related to activities outside the ward and so were unlikely to clash with medical practices. It was the first hospital in Northern Ireland to explore the possibility of using non-hospital accommodation on a temporary or semi-permanent basis. In 1954 it bought a plot for a holiday centre at Tyrella beach in Co. Down for use by patients during the summer months, and in 1961 Dr Berrington (the RMS) suggested the opening of a hostel as a satellite unit for the hospital (Prior, 1993a: 80). In the Annual Report for 1956, the rationale for these initiatives was outlined.

Patients are being encouraged to do things for themselves and by themselves, consequently much of the work on the new holiday home at Tyrella and a great deal of work at the hospital has been carried out by the patients ... The hospital is pursuing its ideal of the therapeutic community, using occupational therapy not as a means of passing time, but as a way to individual development and as a means of contributing to community life and at the same time establishing more and stronger links with what used to be thought of as the 'world outside'. (NIHA, 1957: 35, cited in Prior, 1993a: 80)

The holiday home was used each summer for over three decades by groups of patients. In 1969, at a time when Northern Ireland was entering a period of extreme political violence, a patient who signed herself Susan, wrote of her absolute delight in spending a week there. 
I was out for a week at Tyrella and it was smashing. When I got there I just lay on the couch for a wee while. Then Mary and I went to the beach to the cafe and got some ice cream. Then, when we had finished our pokes, we went into the house again ... On the second day, I lay out on the grass for a while. In the afternoon, Elsie and I went along the sandy beach and into the cafe again. We had a cup of coffee and back again. When dinner time came I had potatoes and butter and then helped the others with the dinner dishes. In the afternoon, I bought four books at the shop. I spent the week wonderfully - we came back yesterday morning. (The Sketch, Aug. 1969: 5)

In the 1970s, both male and female patients went on holidays together at Tyrella, and large numbers of student nurses took part in the fun, which included going for tea at a nearby cafe and swimming in the sea. Health and safety regulations were not so stringent in those days, and Francis, a male patient, tells the reader that some of the supervising nursing students were not even able to swim.

Every day, or at least almost every day after dinner, I went into the now very cold sea water for a swim. The way I enjoy myself is going to the sea up to my waist and then doing the breast stroke. After a few moments I wet my head quiet carefully and do the 'over-arm' or better still the 'crawl'. Then after ten minutes of this I swim under water. The only nurse I found bathing with us was Bobbie Hanvey, although as a matter of fact, I found out he couldn't swim! (The Sketch, Aug. 1970: 10)

Tyrella was not the only holiday venue. Francis, who wrote a long article in The Sketch in August 1968 told of his holiday in a caravan in Warrenpoint, with nine male patients supervised by one male nurse (The Sketch, Aug. 1968: 2). He enjoyed the freedom of going on his own in a motor boat to Omeath to buy a cigarette lighter and to the cinema to see The Absent Minded Professor as well as group outings to local tourist attractions. In his words, 'we all had quite a time'. The reader is left wondering if the 10 men stayed in one caravan or if they had the luxury of two vehicles. Other holiday destinations were used by Downshire, according to Kelly (2012: ch.7), who describes holidays at Butlin's Holiday Camp in Mosney, Co. Meath, and at psychiatric hospitals in Ireland and Scotland.

Holywell did not have a holiday centre, but it had summer outings. During the 1960s, if the weather was good, groups of patients went to various beauty spots such as Newcastle, Bangor and Donaghadee. In Speedwell we read that the Ballycastle Lammas Fair was an annual event enjoyed by the male patients (no explanation for the exclusion of women was given) who 'returned late and tired but happy' (Speedwell, Dec. 1968: 28-9). However, we are also told that the outings were somewhat spoiled because the only available transport was the hospital van. This was a closed vehicle without windows, and the patient experience was 'marred by the fact of not being able to see where' they were going (Speedwell, Autumn 1963: 32). A voluntary effort by staff in the late 1960s led to a 'concert party', a 'Guest Tea' and other fundraising efforts, which resulted in the purchase of a patient mini-bus.

The principles of the 'therapeutic community' were reflected not only in the innovative projects outside the hospital, but also in the organization of sporting and leisure activities on the wards. At Holywell it appears that the staff and patients had a very full social schedule. In 1960 an entertainments officer was appointed to develop physical education, recreation and entertainment, and an art therapy class was started with both therapeutic and diagnostic purposes (NIHA, 1961: 40). In the mid 1960s, the weekly programme included dances on Mondays, concert rehearsals on Tuesdays, films on Wednesdays, and a camera club or debating society (which had more than 120 members in 1959) on Thursdays. On one club night, the principal of Antrim Technical College brought his slides of Ireland to the recreation hall to show to the audience who were then invited to 
show any coloured slides of their holidays as these were 'always of interest to the patients' at future sessions (Speedwell, Christmas 1962: 34). For a period, the debating club's programme centred round 'Tall stories, true or false', which were received with great enthusiasm (Speedwell, December 1968: 29). On weekend evenings, there was a choice on Friday between bingo (for both men and women) or a whist drive, and on Saturday the patients' social club had its meeting. Winter meetings were 'spent in a sing-song and games' under the management of a long-stay patient who had given many years of service (Speedwell, Spring 1972: 29). Patients had to apply to the hospital secretaries to join the club, after which a committee decided whether or not the applicant was 'suitable', and names were subsequently forwarded to the matron or chief male nurse for final approval of membership (Speedwell, Autumn 1965: 40).

At Holywell, there were also events based on radio and television programmes such as the panel game 'Twenty Questions' and musical evenings based on 'Juke Box Jury' and 'Top of the Pops'. Staff and patients competed in all these events. A talent competition catering for all tastes, held in November 1962 at Holywell, included 'instruments, folk songs, pop songs, story-telling, recitation and even the Twist'. The judges were so impressed that they could not pick a 'top winner' and the new Matron presented prizes to all the participants (Speedwell, Christmas 1962: 34).

Because Speedwell ceased publication in 1973, we do not know if the social life of Holywell continued to be as varied as it had been during the 1960s, but it is likely that it did. From The Sketch it is clear that at Downshire both indoor and outdoor games and athletics continued to be a regular feature right through until the 1980s. For example, in 1977 the Recreation Officer, C. Campbell, gives a full-page timetable for recreation and indoor competitions for the following six months (The Sketch, Nov. 1977: 24-7). These included competitions in bowls, darts, quoits, table tennis and draughts, some of which were with clubs from outside the hospital. The events were organized by the patients' recreation committee, which consisted of five or six patients who had agreed the programme with the Recreation Officer.

At Christmas in both hospitals, groups of patients were taken to see the lights and decorations in Belfast city centre, and there were patient concerts and nativity plays. Rehearsals began in early November, a carol service was held in the third week of December and a group of carol singers did a tour or the wards on Christmas Eve (Speedwell, Spring 1972: 28). Every Christmas Day, the Holywell (staff) Dance Band played, and children of staff were given presents by Santa Claus. At Easter, the celebrations included a Good Friday passion play, a concert and, on Easter Monday, parades with prizes awarded for the best bonnets for both men and women. At Downshire, concerts and dances were still in full swing during the 1970s. All events included staff and patients, with support from local musicians. For example in December 1977, there was a very successful folk and variety concert in the Great Hall, and a New Year's Eve dance on 2 January 1978. According to Francis from Ward K. 28:

There aren't a great lot of dancers in our ward, but some of our patients just go to listen to the dance band, whether it be 'Gerry and the Highlights', or Frank Fitzsimmons and the 'Kingsfield Ramblers' ... After about six dances the time wore on to 8.45 and so for our supper we were all given cardboard cups of tea, meat and egg sandwiches, not to mention two pastries and a piece of Christmas cake ... After Auld Lang Syne at $10.25 \mathrm{pm}$ it was time for us all to leave for our wards, and we were all, although it was late, allowed to sit before our various coloured TV sets. (The Sketch, Apr. 1978: 21)

As observed by Goffman (1961: 94), these social activities brought staff and patients together, promoting good relations in what was a 'total institution' for these patients, encompassing every aspect of their lives (for further discussion, see Handler 2009). Unfortunately, it also hindered the 
reintegration of these patients into the wider society to which they hoped to return, as it seemed to many long-stay patients that life was more enjoyable inside the institution than it was in the world outside.

\section{Work as therapy}

At Holywell, in the late 1950s, there were two schemes for the manufacture of boxes and crates for use by 'outside concerns', with an emphasis on the work being therapeutic (NIHA, 1961). The RMS, Dr Smith, was enthusiastic about developing occupational therapy, aiming to extend and reorganize this form of treatment for patients in all departments, arguing that work could be carried out by patients under the supervision of a small number of staff. Smith had faced considerable opposition to his ideas, as they were seen by some as a ruse to secure cheap labour by both patients and staff (Mulholland, 1999: 76). A contemporary report by the King's Fund was also critical of the work carried out in most psychiatric hospitals in the UK at the time. 'The type of work is monotonous and repetitive. At present the work in units is surprisingly lacking in variety and few attempts appear to have been made to encourage and inculcate new skills or to relate work done to the opportunities available in the locality' (Wandsworth and Miles, 1969: 9).

Opposing views on work as therapy can be seen clearly in different articles appearing in Speedwell. Some of these were very positive such as that from a patient who signed himself 'R'. ${ }^{1}$

\section{Holywell house 1967}

Occupational therapy reigns there / A thing of rugs and many ploys / And joy to find one can use one's hands / And incidentally lifts the mind / From such-like things as headaches / And trivial worries / And over all Sister Potter presides / And often has to guide / Our inexperienced and clumsy hands - / It is a happy ship ...

From painting empty tins to / Covering chairs / Below in kitchen Mrs. Alexander taught / The cooking of domestic arts / And last but not least / As a solace to the mind / We repaired to the wooden hut / For painting classes

(Speedwell, Christmas 1967: 41)

However, some contributions, like one from a female patient who signed herself L. McK, from Ward F. 3A, were more ambivalent.

\section{The laundry}

We go to the laundry each morning / with never a frown on our face / We all tackle work without warning / Doing things with precision and grace / We shake and we fold from morning to night / From Monday till Friday at four / When we think we have our work done / The porter brings round a truck more

To the canteen at ten and the canteen at three / Fifteen of us trip in a row /.It's nice to know you have ten minutes break / Till the machines are again on the go / The pressing-machine stands in a spot by itself / Where they press coats and frocks by the score / Then they're all neatly folded and put on a shelf / To await the arrival of more

(Speedwell, Summer 1966: 40).

While this contributor appears to accept the value of this repetitious work, she hoped to look back on it with nostalgia rather than enjoying it for its own sake. In 1964, 'Rara Avis' was characteristically scathing on the issue. 
At Holywell and elsewhere, every whim and fancy of the staff is usually vented upon the patients, and particularly those inclined to servility. One is certainly not reminded of behaviour becoming a hospital ward when a 'crabbit' dictatorial and domineering nurse of whatever calibre literally 'gulders' a patient's surname, and does not request, but commands him to undertake some menial task, such as washing out lavatories, sweeping and polishing floors, hauling and pulling furniture from one end of the hospital to the other, - and not forgetting the doctor or nurse who likes to take advantage of the fact that he can have his car washed and polished for nothing. Quid nunc? (What now?). (Speedwell, Winter 1964: 3-6)

These nurses were, he pointed out, the 'exception rather than the rule'. However, he observed that the forms of work to which patients were 'driven' seldom varied from what in essence constituted 'free and forced labour'. There was some justification in this allegation, as patient labour was not replaced by that of paid domestic and other staff until the early 1970s.

The comment by 'Rara Avis', that work should be carried out in 'bright and congenial surroundings', suggested that conditions were less than ideal in Holywell. He also proposed that it was 'essential' that there was an 'adequate variety of pursuits to cater for as many tastes as possible'. His plea was that the authorities should recognize that all patients were not the same and could not be treated as if they were: 'A man or woman ought never to be asked to do something which is neither interesting nor significant to him or her'. He suggested that 'occupational therapy should, in so far as is possible, be a labour of love, and something which the patient daily looks forward to with enthusiasm' (Speedwell, Winter 1964: 39).

One very successful initiative which originated at Downshire in 1963, and which continues to this day, was the Industrial Therapy Organisation (ITO) now renamed Action Mental Health. Its purpose was to equip patients with skills that could transfer into the workplace. Based on a model that emerged in Bristol, it was the brain child of Tom Page, occupational therapist, who together with Drs Berrington and Donnan, persuaded business men Mr Richard Kew to allow the new organization to use premises at the Talmac factory in Downpatrick and Mr F.C. Tughan to chair the new project. Though based at Talmac, work for patients was not confined to one place. Thanks to the involvement of a number of business men, contracts included the maintenance of sports fields and factory grounds and work on building sites and in local factories. In order to make it easy for patients to participate in the scheme, Ward 9 at the Downshire was designated as the ITO ward, with nursing and domestic staff starting at 5.30 a.m. to make sure that everyone was dressed and fed in time to leave for work at 7.00 a.m. (Kelly, 2012: ch.7). In the mid-1960s, more than 40 patients from Downshire were working in the scheme and, within a few years, patients from other hospitals were also involved in the project. For example, in the early 1970s, 150 patients from Holywell were being trained and employed in real contracts by the ITO (Mulholland, 1999: 82). After operating for 16 years at the Talmac factory premises, Downpatrick, the ITO opened a new purpose-built factory on the Ballyduggen Industrial Estate, Downpatrick (The Sketch, Dec. 1980: 11).

Projects such as the ITO were very successful in helping people who had left work due to their mental illness to return to some kind of working routine after a period in hospital. However, there were concerns about some of the work which purported to be of therapeutic value. In the mid1960 s, the NIHA set up a working party to advise the authority 'generally on all aspects of the therapeutic occupation of mental hospital patients' (NIHA, 1964: 43). The King's Fund Report had found that, in general, there was a lack of 'male jobs where strength and energy are required' (Wandsworth and Miles, 1969: 10). However, in most large psychiatric hospitals, the on-site farm served this function. For example, from its opening in 1899, Holywell had its own working farm (Springfarm) which had a dairy, cattle byres and a horticultural club which was run voluntarily by 
a male nurse. Farm work was viewed by the first RMS as 'a curative agent in the treatment of insanity'. By the late 1960s, Springfarm employed 40 male patients as well as four staff(Mulholland, 1999: 76-82). In 1970 the assistant secretary of the hospital argued that it was 'an economically sound unit' playing a 'very prominent part in the therapeutic occupation of patients within a rural and stable environment' (Speedwell, Christmas 1970: 29). However, the sale of hospital farms was already likely by then as a decision to close the farms at psychiatric hospitals had been made in 1968 (Prior, 2012: xxix).

\section{Staff-patient interaction}

Efforts to modernize psychiatric care at Holywell and Downshire during the 1960s and 1970s were representative of a general move away from a model of containment to one of rehabilitation. Consequently, staff members no longer viewed themselves as simply custodians of chronic patients but rather as health professionals with a valuable contribution to make, not only to caring for patients but to preparing them for their return to the wider society. Efforts to recruit and retain qualified staff included professional training initiatives and the encouragement of social activities aimed at enriching their total working experience.

One of these initiatives was the establishment of Staff Recreation Clubs open to all. Activities included dancing, the formation of a hospital band, badminton, tennis, football, billiards, table tennis, whist drives and staff parties. According to the Management Committee at Holywell, the club had a positive impact on staff recruitment and retention (Mulholland, 1999: 73). The involvement of patients in sporting activities with the staff also enhanced the patient experience. Some of the sports were also open to patients as participants and players, and everyone was welcome as spectators to the sporting events. In the Sketch in August 1971, we read that at Downshire, Male Ward 2 won the inter-ward cricket competition, with a team representing both nurses and patients. Male Ward 10 won the inter-ward putting competition in the same year and the football team from Male Ward 8 was triumphant in the Dr Dougal Cup Final (held annually). The anonymous reporter for The Sketch waxed lyrical on the game.

With only a few minutes remaining, the Babes put in a super finish. Pat Healy - the Mackie Cup star of days gone by - showed his real worth by robbing the incoming Walshe. Here we saw defensive football turned into attack as Pat, in his very cool fashion, passed a long shot to McComb, Gerry was having a field day, all on his own up to the right wing, then goalwards. This move drew Savage and Tumelty, then McComb neatly clipped the ball back to the unmarked Brian Healy - Magorrian sensed the danger and came out to narrow the 15 yard gap but Brian, cool as a cucumber, boldly swerved and flicked the ball into an empty net. (The Sketch, Aug. 1971: 10)

The Dr Dougal Cup Final was again in the news in 1977, when Ward 31 at Downshire won against a team called 'Lay Admin'. In a commentary worthy of any national newspaper coverage, the anonymous contributor gave readers of The Sketch a colourful description of the game.

At the other end, Nelson, giving a fine display of neat defensive football, was a treat to watch. He was well supported by M. Killen and keeper McAlinden in curtailing the crafty probing of Murphy, Mahon and Dalzell. However, Murphy collecting a neat pass from Mahon should have scored the equalizer, his 15 yard drive sent harmlessly wide. (The Sketch, November 1977: 11)

From the 1950s, teams from both hospitals were involved in competitive sporting activities with the other psychiatric hospitals in Northern Ireland. In 1968, the Holywell patient indoor bowling 
team with 20 members played against Londonderry and Gransha Hospital and the Tyrone and Fermanagh Hospital. According to Speedwell (Dec. 1968: 28), the excitement among the participants was 'difficult to stifle'. Badminton, football, floor-golf and peg quoits (for patients aged 50 to 70 years) were all played competitively in an inter-hospital league system (Speedwell, Summer 1971: 20-1). These games were still being played competitively in 1979, when Downshire 'outclassed all opposition in the three hospital play-off in the inter-hospital floor golf, quoits and clingball competitions' held at Purdysburn hospital that Summer (The Sketch, Dec. 1979: 13). In the same issue, we hear that the golfing section of the recreation club was also thriving, with monthly competitions held on golf courses at Warrenpoint, Spa, Ardglass and Downpatrick.

From the accounts in both hospital magazines, it is clear that those with sporting, musical or artistic skills among all ranks of staff were encouraged to take part as both instructors and competitors in the broad range of activities that ran within the hospitals and were showcased at the annual competitions between them. However, interaction between staff and patients was not necessarily always full of laughter and good humour. Nor did the status differential between staff disappear. According to Mulholland (1999: 98), discipline on the wards at Holywell continued to be strict until 1967, with nurses having to 'stand to attention as doctors passed through wards'. 'Rara Avis', a patient who had been 'coming to and from Holywell Hospital for a dozen years' did not see much evidence of the democratic therapeutic community envisioned by the RMS. On the contrary, he claimed that all too often the institution forgot that 'the patient is the most important person in any hospital' alleging that 'the true role of the patient has been conveniently sacrificed on the altar of something approaching hero worship for the staff and of the medical staff in particular (Speedwell, Winter 1964: 36).

The following 5-verse poem from a long-term patient at Holywell, Robairt Clough, gives us a perspective on staff roles in 1972.

\section{Holywell Rhymes}

Little drops of medicine, / Little coloured pills, / Cure us of all ailments, Cure us of all ills.

Doctors with a stethoscope, / Doctors with a bag, / Make us fit and healthy, / Cheer us when we flag.

Pretty little nurses / Nurses bold and strong, / Nurses with a banjo, / Nurses sing a song.

Wardsmaids with the dinner, / Wardsmaids with the tea, / Keep our tummies happy, / Until the day we're free.

Little drops of medicine, / Little coloured pills, / Settled all our ailments, / Cured us of our ills

(Speedwell, Christmas 1972: 29)

In contrast to this rather positive view of staff, 'Rara Avis' pointed out the irony of the situation when at times patients were happier than those who cared for them. 'How Irish it is to find certain doctors and nurses with faces like tin-openers, brow beaten by anxiety and seriousness of mind, coming along to try making us happy. Hie, ye Gods!'(Speedwell, Winter 1964: 41)

At Downshire, each issue of The Sketch had short notes welcoming new staff by name, saying goodbye to those retiring, congratulating those who had passed examinations or got married, and sympathizing with those who had lost relatives. For example, in 1976 Joe Craig, Deputy Charge Nurse, retired after 28 years of service, Nurse Margaret Harris got married, Pauline Kell and Linda Nesbitt started their placements as occupational therapy students, Hugh Cunningham retired from the Engineer's Store, Alan Charles started as the new catering manager, and Miss D. Gillings replaced Miss B. O' Hare as District Administrative Nursing Officer (The Sketch, Christmas 1976). As many patients spent years at the hospital, these members of staff were valuable members of their circle of friends. 


\section{Combating stigma}

Goffman (1961: 96) observed that people who are stigmatized often organize themselves into groups and networks and often represent themselves through newsletters, magazines and books. Though the reality of stigma was rarely discussed in either of the magazines explored here, it did appear occasionally. The following article by an 'Ex-patient', who had been both a nurse and a patient, is one example of the impact of social stigma.

To many temporary patients ... it was a turmoil before they entered Holywell Hospital and from the first day began their recovery, step by step ... until the giant step of facing the public and their friends, who knew they had been patients. I, myself have worked as a mental nurse and used to be amazed at the things people said to me when they learnt of my occupation. 'You must need great patience to deal with those'. (Speedwell, Apr. 1968: 25)

Rejection by the general population had an impact not only on individual patients but also on new initiatives involving patients. For example, beginning in 1955, a group of 30 patients from Holywell, accompanied by three members of staff, had taken a week's holiday in the north Antrim coastal town of Carnlough. The RMS was so impressed by the 'improvement in their conditions and appearance generally, brought about by this temporary change of environment' that he suggested in 1956 that a permanent holiday home be purchased. It was hoped that it would be of benefit to long-stay patients for an annual holiday and for those 'progressing towards recovery' as a convalescent and rehabilitation centre where patients could become 'better conditioned to normal civilian life' away from institutional life 'in an informal carefree atmosphere' (Mulholland, 1999: 59). This was more difficult than was anticipated and the purchase of a house in Portrush, a busy seaside resort, did not go ahead. In the first issue of Speedwell in 1959, a contributor wrote that "the Portrush people would not agree to our taking a house in the town to use as a holiday home and convalescent unit' (Speedwell, Summer 1959: 10).

In order to combat stigma in the Antrim area, a public relations exercise was launched to 'lessen public prejudice against mental illness and mental hospitals' (Mulholland, 1999: 64). In 1960 a Belfast Cine Film Group produced a short film about Holywell, and contacts with organizations such as churches and professional bodies were used to encourage organized visits to the hospital. In that year alone, 1400 people visited it. However, the heightened profile of the hospital was not without its problems. In 1961, an unnamed 'observer' wrote in Speedwell of this public relations exercise as an 'ever-growing tendency to over-run the hospital with groups of visitors of all kinds'. While accepting the benefits of outside scrutiny, the writer argued that there was a danger: ' $\ldots$ of making show-places of such institutions. Many members of the public are inclined to regard their visits in the nature of visits to the zoo - on the look-out for the macabre casting furtive glances at the 'inmates' - especially while being led through the dining-rooms at meal hours.' (Speedwell, 1961: 11). The 'observer' argued that the feelings of patients, especially 'the more sensitive', were upset by the 'intrusion of strangers'. However intrusive it was, the initiatives to break down barriers between the institution and the surrounding population did eventually bear fruit.

\section{The 'troubles'}

In parallel with changes in mental health policy, the 'troubles' were at their height in 1972. Concerts and sporting matches as well as inter-hospital events, such as prize-giving and 'get-togethers', were cancelled due to the civil unrest (Speedwell, Spring 1972: 28). According to reports in the 
hospital magazines, patients and staff were 'bitterly' disappointed. While a few tournaments were played among Holywell patients, there was 'not quite the same interest'. A contributor to the same issue of Speedwell lamented: 'still, one keeps on hoping times will return to normal soon, and we will be able to travel and take part in the usual competitive games'. The following year, the ban on travel was lifted, and life at Holywell returned to normal (Mulholland, 1999: 86). However, the conflict in Northern Ireland permeated every aspect of life (O'Reilly and Stevenson, 2003). Two poems in Speedwell by Robairt Clough give us some idea of how the political situation affected one patient.

For there's shooting and there's murder there, / And dark deeds in the night / Why in our land of beauty / Must we Irish always fight? / ... I hope I'll live to see the day / When all the hatred's gone

(Speedwell, Easter 1973: 35)

His second poem expressed his distress at the conflict and his boredom in hospital.

\section{Mo(u)rning ' 71}

No pulsing life is ours to know / The world is but a picture show / The 'box' the press, the subtle rumour / Spreading like an ugly tumour / Hear the country's going to ruin / Instead of being up and doing.

Soldiers shot and houses burning / Bricks are flying, children crying / That's the way my thoughts are turning / Although at heart for home I'm yearning / Fireside glow and children's laughter / These are what I'm longing after

Yet here am I in dull confinement, / Tho' modern methods, all refinements / A patient still, impatient yet / To see the wider fields beyond / Slieve Donard, where the heather blows / E'en last night I dreamed of snows / Of sea and mountain, bog and heather / But woke to find a shapeless shadow / Let me roam and let me wander / Through the sunny world out yonder / Mournes I long for / I'm not done for / Morning's here but I'm in mourning / But perhaps this lane will have a turning / Travel along - sing a song / Don't fence me in

(Speedwell, Christmas 1973: 16-17)

At Downshire hospital, the 'troubles' also made an impact on some of the patients. In 1972 Winifred Gray from Ward 10 expressed her horror at what was going on.

\section{Peace in our time}

What is wrong with this fair land of Ireland / The home of scholar and Saint / Ravaged by the terrorists bomb and gun / Smeared by a bigoted taint / Fear and hatred have stalked this land / Rearing its ugly head / And it leaves in it's wake as it goes it's [sic] way / Destruction and innocent dead / When I look from my window over rolling green fields / I find it hard to believe / In the murders and bombing and the snipers gun / And the death that these episodes yield /And some don't know what they're fighting for / Just destruction and death they love / And if, as they say, there is a God / Then I pray to the heaven above / The plea that comes to the age old words / 'Give peace in our time, Oh Lord!'

(The Sketch, Sep. 1972: 4)

Peace did not come for another two decades, and life continued as usual in the large psychiatric hospitals in Northern Ireland. However, even in these protected spaces, life was changing. 


\section{The end of an era}

The last issue of Speedwell was published at Christmas 1973. It was a much smaller version of the magazine; not only had the number of pages shrunk from 52 to 23, but the production team had fallen from 23 to nine. There were difficulties in obtaining contributions, as many of those responsible for the magazine had been transferred to new positions in the restructured health services. The long-serving editor, who had held the position since 1959, resigned in order to encourage 'an infusion of new blood'. In-patient numbers were reducing as were the sporting and leisure activities. The only 'sport' mentioned in this issue was draughts, and the Northern Ireland Mental Health Association (Antrim Branch) appears to have been the only provider of evening activities. It met just once a week and organized a monthly speaker. Other articles in this issue included recipes, fashion and beauty, notices contributed by the Nurses' Christian Fellowship and Domestic Staff Notes (Speedwell, Christmas 1973: 5). By 1973, facilities In Holywell Hospital 'were generally cramped', occupational therapy was 'substandard', and the hospital farm (Springfarm) was in the process of being sold (Mulholland, 1999: 82).

At Downshire, the therapeutic community ethos continued to thrive throughout the 1970s and 1980s, with The Sketch being published as part of this project until 1987. However, by then the number of activities on offer to patients had been reduced, but the occupational therapy department continued to thrive. A number of management changes had a significant impact on the in-patient experience. In keeping with the general policy decision at the NIHA, the hospital farm was discontinued in the early 1970s and, due to the reorganization of nursing education, Downshire lost its nursing school in 1974. An increased emphasis on rehabilitation followed the opening of a specialist unit in 1983 and led to the transfer of some patients to ordinary houses in local estates (known as Intensive Nursing Care Homes) with outreach workers to help them to adjust to normal life (Kelly, 2012: ch.9). All these changes were viewed by some as a downgrading of the hospital, as patient and staff numbers declined.

A decade later, in 1998, research on the experiences of in-patients in Holywell, suggested that the period covered by Speedwell was a time when Holywell was at its most active. For patients in the 1990s, some of whom had many admissions (up to 16) for periods of a few days to seven months, the experience was one of boredom. 'Several interviewees cited the evenings as being difficult to fill'. Comments included: 'Evenings are a long time, there's an awful shut-in feeling'; 'Actually there's nothing to do but sit and wait, you could be waiting for the next meal, television's difficult because concentration isn't the best' (NHSSB, 1998: 21). The only activities seemed to be limited occupational therapy, relaxation classes and a 'multi-gym'. Patients said: 'we sort of sat and chatted most of the day' among themselves. Other research has shown that changes in psychiatric care have not necessarily led to a better in-patient experience (DH, 2002). Although many improvements have been made in hospital-based care, evidence from the early twenty-first century indicates that there is 'incontrovertible and compelling evidence' that service users find hospital care 'neither safe nor therapeutic' (Haigh, 2002: 380).

\section{Conclusion}

In this article, two hospital magazines have been explored to see what they tell us about life for patients in large psychiatric hospitals in Northern Ireland during the 1960s and 1970s. This study has shown that for some patients, the magazine provided a unique and valuable forum for their literary talents. It also allowed them to air some of their grievances and offer 'constructive' criticism. As each hospital magazine was produced by both staff and patients, it also reduced barriers 
between them and added to the sense of community. However, it has also shown us that these were protected worlds within a world which was very different and often frightening to those who tried to return to their ordinary lives. These magazines are representative of their time and place and as such provide insights, not only into the lives of the contributors but also into the approaches to mental health care during this very important period of transition.

\section{Acknowledgements}

We would like to thank: the Wellcome Trust, London, which partially funded the research for this article (Grant 081157/Z/06/Z/AW/HH); Dr Sean Kelly who supplied copies of The Sketch and expert advice on Downshire; and library staff at Queen's University Belfast who helped us to access copies of Speedwell.

\section{Note}

1. In Speedwell, the 2-verse poem was set out in short lines. This and other poems are reprinted here with line endings indicated by slashes.

\section{References}

Adams A (2008) Medicine by Design: The Architect and the Modern Hospital, 1893-1943. Minneapolis: University of Minnesota Press.

Barton R (1959) Institutional Neurosis. Bristol: John Wright.

Beckett C (2006) Thatcher. London: Haus Publishing.

Campling P (2001) Therapeutic Communities. Advances in Psychiatric Treatment 7: 365-372.

DH (2002) Mental Health Policy Implementation Guide: Acute Inpatient Care Provision. London: Department of Health.

Down Hospital (1930) Annual Report of the Down County Mental Hospital. Unpublished report held in the archives of the Downshire Hospital, Downpatrick.

Friedman LD (ed.) (2004) Cultural Sutures: Medicine and Media. Durham, NC: Duke University Press.

Gavigan AC (1963) The mental hospital magazine. Psychiatric Quarterly 17: 243-248.

(9) ffman E (1961) Asylums: Essays on the Social Situation of Mental Patients and Other Inmates. New York: Anchor Books, Doubleday and Co.

GB Royal Commission (1957) Report of the Royal Commission on the Law Relating to Mental Illness and Mental Deficiency 1954-1957, London: HMSO.

(D) pndler R (2009) Erving Goffman and the gestural dynamics of modern selfhood. Past \& Present 203 (Suppl. 4): $280-300$.

Haigh R (2002) Acute wards: problems and solutions. Modern milieus: therapeutic community solutions to acute ward problems. Psychiatric Bulletin 26: 380-382.

Jones K (1993) Asylums and After: A Revised History of the Mental Health Services: From the Early Eighteenth Century to the 1990s. London: Athlone Press.

Kelly S (2012) A Grand Old Lady: Downshire Hospital 1869-2011. Belfast: Eastern Health and Social Services Trust.

Manning N (1989) The Therapeutic Community Movement: Charisma and Routinisation. London: Routledge.

Mills AB (1965) Hospital Public Relations Today. Chicago: Physicians Record Co.

Mulholland M (1999) To Care Always: 100 Years of Holywell Hospital, Antrim, 1898-1998. Antrim: Holywell Hospital.

NHSSB (1998) Centre Voices: Experiences of people who have been in-patients in Tobernaveen Centre, Holywell Hospital. Ballymena: Northern Health and Social Services Board. (Available in the library at Queen's University Belfast)

NIHA (1957) Annual Report of the Northern Ireland Hospitals Authority for 1956. Belfast: Northern Ireland Hospitals Authority (available at PRONI, HOS/1/2/9). 
NIHA (1961) Annual Report of the Northern Ireland Hospitals Authority for 1960. Belfast: Northern Ireland Hospitals Authority (available at PRONI, HOS/1/2/13).

NIHA (1964) Annual Report of the Northern Ireland Hospitals Authority for 1963. Belfast: Northern Ireland Hospitals Authority (available at PRONI, HOS/1/2/16).

O'Reilly D and Stevenson M (2003) Mental health in Northern Ireland: have 'the Troubles' made it worse? Journal of Epidemiology and Community Health 57(7): 488-492.

Powell E (1961) Address to the National Association of Mental Health Annual Conference, 9 March 1961. Accessed (July 2013) at: http://www.nhshistory.net/watertower.html

Prior PM (1993a) Mental Health and Politics in Northern Ireland: A History of Service Development. Aldershot: Avebury.

Prior PM (1993b) Mental health policy in Northern Ireland. Social Policy and Administration: 27(4): 323-334.

Prior PM (ed.) (2012) Asylums, Mental Health Care and the Irish 1800-2010. Dublin/Portland, OR: Irish Academic Press.

Reznick J (2004) Healing the Nation: Soldiers and the Culture of Care-giving in Britain during the Great War 1914-1918. Manchester: Manchester University Press.

'Speedwell', the magazine of Holywell Psychiatric Hospital, Antrim. Unpublished; some issues held in the library of Queen's University Belfast .

'The Sketch', magazine of the Downshire Psychiatric Hospital, Downpatrick. Unpublished; a complete set of issues is held in the Archives of the Downshire Hospital, Downpatrick.

Wandsworth N and Miles A (1969) Industrial therapy in psychiatric hospitals. A King's Fund Report. London: Ministry of Health. 